\title{
Quipazine Maleate
}

National Cancer Institute

\section{Source}

National Cancer Institute. Quipazine Maleate. NCI Thesaurus. Code C66502.

The maleate salt form of quipazine, a piperazine-based nonselective serotonin (5-HT)

receptor agonist with antidepressant and oxytocic activities. Quipazine targets and binds to serotonin receptors, particularly to the $5 \mathrm{HT} 2 \mathrm{~A}$ and $5 \mathrm{HT} 3$ receptors. Serotonin

receptor activation by quipazine may lead to smooth muscle contraction and antidepressant effects. 